Review

\title{
Post-neutering urethral sphincter mechanism incompetence in female dogs
}

Received: aug 2020; Accepted: oct 2020

\author{
Luciana de Jesus ${ }^{1}$, Milena Cleff de Oliveira ${ }^{2}$, Álan Gomes Pöpp1 $1^{1,3^{*}}$
}

\begin{abstract}
Female dogs neutering is a routine surgery that aims to prevent diseases as well as to help populational control. Urinary incontinence is one of the most significant unwanted consequences following the procedure. Pharmacological treatment is recommended for such case, and alpha-adrenergic and estrogenic drugs have been the most frequent choices reported in literature. Besides, tricyclic antidepressants are also able to control clinical signs. The exact mechanism involved with this condition is not yet fully understood. Estrogen deficiency with a subsequent loss of urethral tonus is believed to trigger clinical signs. However, it is possible that other factors such as gonadotropins and gonadotropin-releasing hormone levels may play a part on this complex mechanism of the post-neutering urinary incontinence.

Keywords: spaying, urinary incontinence- estrogen deficiency, gonadotropin, tricyclic antidepressant, Canis lupus familiaris.
\end{abstract}

\section{Introduction}

Ovariohysterectomy is one of the most performed procedures in veterinary medicine, and its benefits are: population control, prevention and treatment of reproductive tract diseases, prevention of mammary neoplasms (SALAS et al., 2015), aid in correction of eventual behavioral disturbances as well as a protective factor against the development of diabetes mellitus (PÖPPL et al., 2017).

\footnotetext{
${ }^{1}$ Programa de Pós-Graduação em Ciências Veterinárias (PPGCV), Universidade Federal do Rio Grande do Sul (UFRGS). Av. Bento Gonçalves, 9090; Agronomia, CEP: 91540-000, Porto Alegre, Rio Grande do Sul, Brasil.

${ }^{2}$ Faculdade de Veterinária (FaVet), Universidade Federal do Rio Grande do Sul (UFRGS).

${ }^{3}$ Departamento de Medicina Animal, Universidade Federal do Rio Grande do Sul (UFRGS).

* Corresponding author: gomespoppl@hotmail.com

Av. Bento Gonçalves, 9090; Agronomia, CEP: 91540-000, Porto Alegre, Rio Grande do Sul, Brasil.
} 
However, it could have undesired consequences, such as postneutering urinary incontinence, which is defined as the involuntary loss of urine (ABRAMS et al., 2002). Female dogs affected by this condition may be more predisposed to inferior urinary tract infection and skin diseases (GREGORY, 1994), thus affecting their welfare. Besides, urinary incontinence may jeopardize the relationship between the dog and its owner by making it harder to care for the animal and must, therefore, be considered during the decision process whether to undergo the surgery.

At the present time in veterinary medicine, studies suggest that postneutering urinary incontinence in bitches is often undiagnosed. Among drug options for its treatment there are alpha adrenergic agonists and/or estrogens (REICHLER and HUBLER, 2014). There are also reports on the usage of tricyclic antidepressants as effective treatment of urinary incontinence clinical signs once this class of drugs presents urinary retention as side effect.

\section{Background}

The first studies that relate estrogen to urinary tract function are from human medicine. In 1926 the first commercial preparations of estrogen were available to relieve menopause symptoms with urinary incontinence among those (REKERS et al., 1992).

In veterinary medicine, post-neutering urinary incontinence in bitches was reported over 50 years ago (JOSHUA, 1965). Recent studies have shown that such occurrence is more complex than simple lack of estrogen, and focus on changes on vascularity, tissue structure, hormone receptors and urethral collagen distribution (BYRON et al., 2017). 


\section{Inferior urinary tract}

\section{Anatomy}

Bladder and urethra are the main organs involved in micturition. The bladder, which is covered by a transitional epithelium, is an elastic organ, and its size varies according to its filling. It consists of three anatomical regions: neck, body, and apex. The vesical trigone boundaries are the internal urethral opening and the right and left ureters orifices. The bladder receives innervation from the hypogastric (sympathetic) and pelvic nerve (parasympathetic), which innervates the bladder and the internal urethral sphincter. The pudendal nerve innervates the external urethral sphincter, and it is responsible for the somatic innervation of the striated urethral muscle (APPLEGATE, OLIN and SABATINO, 2018). On the vesical wall, there is the detrusor smooth muscle, whose fibers reach out in many directions; an important anatomic detail so that the organ can shrink in size during voiding phase (ROSS, 2013). The involuntary urethral sphincter (internal) is made of dense circular layer of fibers which folds around a layer of longitudinal smooth muscle, where elastic fibers, collagen, lamina propria and capillary network are found. On the other hand, the voluntary urethral sphincter (external) is composed of striated muscle fibers and surrounds the middle third of urethra (TANAGHO, 2008).

The urethra is formed by four histological layers: epithelium, submucosa, muscle and fibroelastic connective tissue. The epithelium is squamous in the distal urethra, and as it approaches the bladder it becomes transitional. In females, the urethra is short and goes from the bladder neck until the external urethral meatus, opening in a tubercle where vagina and vestibule meet (DYCE, WENSING and SACK, 2004). 


\section{Physiology of micturition}

Urine flows to the bladder through the ureters, whose oblique insertion forms ureterovesical valve preventing urine reflux (DYCE, WENSING and SACK, 2004; REECE, 2015a). When the bladder contracts, its muscle laminae converge to the organ neck, lowering urethral resistance. The lumen in the bladder neck is kept closed by passive tension of the musculature (ACIERNO and LABATO, 2019). The bladder's transitional epithelium allows the organ to go through filling and voiding phase (REECE, 2015a). During roughly 99\% of time, the bladder remains in its filling phase, and the several voiding phases that take place during a day represent the remaining 1\% (BYRON, 2015).

The urethra is responsible for conducting urine from bladder to outside of the body. The contraction of external sphincter prevents urine loss. The contraction of this sphincter combined with the passive tension created by elastic elements of bladder mucosa prevent urine from being eliminated during the filling phase (BYRON, 2015). The sympathetic innervation (hypogastric nerve) contributes to bladder relaxation, bladder neck closure, and parasympathetic system (pelvic nerve) inhibition, which contracts the bladder and relaxes the sphincter. The somatic innervation (pudendal nerve) maintains both tonus in pelvic floor musculature and in striated periurethral musculature (ROSS, 2013; APPLEGATE, OLIN and SABATINO, 2018). When the sphincter relaxes and the bladder muscle contracts, urine is eliminated (REECE, 2015a). Adjustment of the bladder muscle and the sphincter is done by information that ascends through the medulla. The influence of cerebral cortex is predominantly inhibitory, whereas the brainstem facilitates micturition (ROSS, 2013).

Bladder's filling phase is controlled by hypogastric nerve through the stimulus of B-adrenergic receptors on the bladder wall, which relax the detrusor muscle, and through the stimulus of $\alpha-1$ receptors in the proximal 
urethra, which contract the organ wall (BYRON, 2015). Besides keeping the pelvic floor muscles tonus, the pudendal nerve stimulates the skeletal musculature of distal third of urethra to contract under voluntary control. Furthermore, through both neurotransmitters noradrenaline and serotonin, the pudendal nerve maintains the urethral sphincter contracted (REECE, 2015b; ACIERNO and LABATO, 2019).

In the voiding phase, micturition control is executed by parasympathetic through acetylcholine release and pelvic nerve action. The inhibition of sympathetic stimulus to the bladder and urethra, through the inhibition of hypogastric and pudendal nerves, causes both organs to relax (ACIERNO and LABATO, 2019). This phase is signaled when vesical capacity is reached, causing detrusor muscle stretching. Such muscle produces afferent threshold stimulus that, after being processed by the cortex, triggers the voluntary process of emptying (BYRON, 2015). Micturition reflex can be overruled by voluntary activation. So, external sphincter can be both controlled by reflex and voluntarily, and this explains why dogs mark territory and why it is possible for dog owners to housebreak their dogs (DYCE, WENSING and SACK, 2004; REECE, 2015a; BYRON, 2015).

\section{Pathogenesis of post-neutering urinary incontinence}

Urine involuntary loss affects from 3,5 to $20 \%$ of bitches that undergo ovariohysterectomy (ARNOLD et al., 1989; CESARE, FERRARI and ROMAGNOLI, 2013; FORSEE et al., 2013; APPLEGATE, OLIN and SABATINO, 2018) in relation to less than 1\% in intact bitches or males, regardless of being neutered or not (COIT et al., 2008). The average time between castration and the onset of signs is 2,9 years, but manifestations of incontinence may occur from months up to ten years after the procedure (THRUSFIELD, HOLT and MUIRHEAD, 1998). The exact mechanism of 
acquired post-neutering urinary incontinence in bitches is not completely clear. Estrogen deficiency in spayed females is believed to lead to a type of urinary incontinence known as "urethral sphincter mechanism incompetence" (USMI), which involves not only the urethra smooth muscle but submucosa vasculature and urothelium, culminating in urethra insufficient closure (REICHLER and HUBLER, 2014; BYRON, 2015). Although less frequent, USMI can also occur in males (ROSS, 2013).

Estrogen receptors presence in the inferior urinary tract has been demonstrated (BATRA and IOSIF, 1983), and such receptors can be detected in the vesical trigone, in the urethra and in the connective tissue around it, which justifies the deleterious effects on the urinary tract of bitches post-neutering with the reduction of circulating estrogen.

Besides, collagen reduction in periurethral structures due to the dog's age, and a decline in adrenergic receptors sensitivity in urethra, are also factors that may contribute to USMI (ROSS, 2013). Bladders with abnormal position, obesity and anatomic anomalies in vagina or vestibule may also contribute to the condition. Some studies show that neutered bitches present higher collagen percentage on bladder wall, and thus a lesser proportion of smooth muscle, in relation to intact females (COIT et al., 2008; PONGLOWHAPAN, CHURCH and KHALID, 2008). However, despite the divergence from other studies that state that collagen levels increase in neutered bitches (CHEN et al., 2002; ROSS, 2013), incontinence could be explained not only as muscle strength loss, but also as alteration in sensory threshold for cholinergic stimulation, as it has been described for women with acquired urinary incontinence (CHARLTON et al., 1999).

In human medicine, stress urinary incontinence (SUI) occurs in women pre- and post-menopause and post-neutering urinary incontinence in bitches is suspected to happen through a similar mechanism, in other words, hormone deficiency in both cases (BYRON et al., 2010). In humans, menopause may decrease collagen type I synthesis, causing depletion of the 
tensile strength in the muscles supporting bladder and urethra, and depletion of the resistance of the vagina walls, contributing to incontinence (MOALLI et al., 2004). In veterinary medicine, a study analyzing collagen and actin expression in urethra of intact and neutered females through immunohistochemistry could not find significant difference in collagen types expression evaluated; and although this study evaluated bitches after one year of neutering, literature shows that the mean age for the onset of urinary incontinence is 2,9 years post-neutering (ARNOLD et al., 1989; AUGSBURGER and OSWALD, 2007).

Additionally, another study did not describe difference in the collagen proportion between intact and spayed bitches, although tissue from incontinent bitches was not evaluated. Such research has evaluated only young and middle-aged females, therefore, the absence of deleterious effects of age on collagen fibers may have interfered with results (BYRON et al., 2010). However, there does not seem to be a consensus regarding collagen deposition in bladder due to low estrogenic stimulus in bitches.

Unlike divergences about collagen, the hormonal role in postneutering urinary incontinence is widely accepted. Both in spayed bitches and in postmenopausal women, gonadal steroid deficiency ends up decreasing or eliminating negative feedback in the hypothalamus hypophysis axis, and as a result there is increased release of gonadotropin releasing hormone $(\mathrm{GnRH})$ by hypothalamus and consequently of luteinizing hormone (LH) and follicle stimulating hormone (FSH) by hypophysis (COIT, DOWELL and EVANS, 2009).

Constant elevation of LH and FSH post-neutering may be crucial for urinary incontinence occurrence, having more significant role than estrogen deficiency per se (REICHLER et al., 2005), once an important part of spayed bitches does not respond to treatment with estrogen as well as there is no important difference in estrogen levels between spayed incontinent bitches and intact continent bitches in anestrus (RICHTER 
and LING, 1985; NICKEL, 1998). Nevertheless, studies show that incontinent neutered bitches present lower levels of gonadotropins than continent neutered bitches, creating the hypothesis that a low endogen GnRH production is involved in incontinence pathogenesis (REICHLER et al., 2005). Although the mechanism is still unclear, it has been demonstrated that messenger RNA (mRNA) presence codifying LH and FSH receptors is upregulated in bladder and urethra of bitches in anestrus in relation to intact males (WELLE et al., 2006; PONGLOWHAPAN et al., 2007). An inverse correlation between in vitro bladder contractility and mRNA levels for $\mathrm{LH}$ and FSH receptors in such organ has already been observed (COIT, DOWELL and EVANS, 2009), with acquired urinary incontinence bitches presenting higher mRNA levels for both receptors and lower levels of bladder contractility, suggesting that such receptors may be involved in the pathogenesis.

Dogs neutering is associated with lower response from detrusor muscle, which could lead to lower contractility force, increasing susceptibility to post-neutering incontinence. Low prevalence in neutered male dogs may be explained due to a longer urethra and its passage through penile structures that provide greater closure pressure (COIT et al., 2008). However, the fact that USMI is occasionally reported in males (PALERME et al., 2017), strengthens the hypothesis that chronic increase in gonadotropins may be more relevant in the pathogenesis of this disease than the fall of estrogen per se.

Prostaglandins that act on inflammation also regulate contraction of smooth muscle (HARVEY and FERRIER, 2012). Study has evaluated expression of four subtypes of prostaglandin receptors in the urinary tract of dogs: EP1 (smooth muscle contraction) EP2, EP3 and EP4 (smooth muscle relaxation) (USHIKUBI, HIRATA and NARUMIYA, 1995). When comparing intact and neutered dogs, it was noted that intact dogs present higher receptors expression in proximal urethra, concluding that both presence and 
subtype receptor vary according to animal's gonadal status. Even though tissue samples from incontinent bitches were not analyzed, differences in prostaglandin receptors expression may be related to urinary incontinence (PONGLOWHAPAN, CHURCH and KHALID, 2010).

Another study has evaluated that there is difference in glycosaminoglycans (GAGs) presence in inferior urinary tract of male and female dogs, intact and neutered, showing that among neutered dogs, females have a significant reduction in GAGs composition (PONGLOWHAPAN, CHURCH and KHALID, 2011). GAGs are components of extracellular matrix along with elastin and collagen, acting on cell support and tissue remodeling; they are also involved in cell growth, maintenance, and epithelium differentiation, as well as maintenance of functional integrity of the urinary tract (NATHAN, SPORN, 1991; MITRANO et al., 2010; PONGLOWHAPAN, CHURCH, and KHALID, 2011). Bearing that in mind, it is possible to see that neutering, regardless of sex, can modify GAGs composition in bladder and urethra of dogs, and once the differences in composition are more prominent in females, there is a suggestion that GAGs may also be part of the factors related to post-neutering incontinence (PONGLOWHAPAN, CHURCH and KHALID, 2011).

Therefore, it is possible to conclude that incontinence is multifactorial and caused by changes in periurethral tissues, decrease in muscle responsiveness and likely by hormone mediated mechanisms (REICHLER and HUBLER, 2014; BYRON, 2015).

\section{The role of estrogen}

Estrogen's main function is to trigger cellular proliferation with consequent tissues growth involved in reproduction, such as vaginal epithelium, endometrium, and mammary glands. Besides, estrogen takes 
part in $\mathrm{GnRH}$ modulation and in ovulation. Estrogen is also responsible for sexual receptivity (GOFF, 2015; HEESCH, KLINE and HASSER, 2015; REECE, 2015c).

Regarding the urinary system, studies have already shown that estrogen sensitizes the receptors of proximal urethra, increasing their contractile strength (SCHREITER, FUCHS and STOCKAMP, 1976). In women, studies indicate that estrogen is related to urethral resistance increase, higher bladder sensory threshold, increase of a-adrenergic receptors sensitivity in urethra smooth muscle and relaxation of detrusor muscle through its action in beta-3 receptors (SCHREITER, FUCHS and STOCKAMP, 1976; ROBINSON and CARDOZO, 2003; MATSUBARA et al., 2002).

\section{Differential diagnosis for urinary incontinence}

Among micturition disorders there is a wide array of alterations that may trigger urinary incontinence. They can be didactically divided into neurological or non-neurological causes (WARE, 2006; ROSS, 2013; BYRON, 2015), with the latter being one of the main differentials for USMI.

Anatomic abnormalities are among non-neurological causes. They can happen in both sexes, being more common in females, and clinical signs are present in the beginning of the animal's life. When the onset happens later, the presence of other concomitant diseases is investigated. Ectopic ureter is the most common cause of anatomic abnormality (BARTGES and CALLENS, 2015). It is considered ectopic the ureter that ends in any other local but not the vesical trigone. It can be unilateral or bilateral, and its most common presentation is when one of the ureters goes down the bladder wall and opens in the urethra (ROSS, 2013; NÕEL, CLAEYS and HAMAIDE, 2017). Less frequent causes of anatomic abnormalities include urethrorectal fistulae, urethrovaginal fistulae, shortened urethras, bifid vaginas and persistent urachus (ROSS, 2013; BARTGES and CALLENS, 
2015; CALLARD et al., 2016). Vaginoscopy and urethrocystoscopy techniques is extremely useful in the investigation of the aforementioned abnormalities (MORGAN and FORMAN, 2015).

\section{General risk factors for USMI}

Incontinence prevalence in spayed bitches goes from 3 to $20 \%$ (ACIERNO and LABATO, 2019), and in bitches with over $20 \mathrm{~kg}$ prevalence reaches $30 \%$, meaning that animal size is important risk factor (BYRON, 2015; BYRON et al., 2017). Breeds with a greater prevalence are German Shepherd, Rottweiler, Dobermann, English Shepherd, Boxer, Irish Setter, English Springer Spaniel and Weimaraner (ARNOLD et al., 1989; HOLT and THRUSFIELD, 1993). In a study about risk factors for post-neutering urinary incontinence performed in southern Brazil, the Rottweiler, Labrador, and Pitbull breeds were classified as having greater risk (LEUPOLT et al., 20204).

The procedure type done during neutering does not seem to have an influence in the occurrence of incontinence (ANGIOLETTI et al., 2004). A study that compared the occurrence of USMI in bitches that underwent laparoscopic ovariectomy or video assisted ovariohysterectomy has demonstrated that the technique used did not have a later impact in the occurrence of USMI. However, previous occurrence of urinary tract infection and/or urolithiasis is considered a relevant risk factor (CORRIVEAU et al., 2017).

It has been suggested bitches that underwent the caudectomy procedure would be more susceptible to develop USMI (HOLT and THRUSFIELD, 1993). Nonetheless, intact bitches from breeds with docked tails rarely present with this type of incontinence, and this relationship

\footnotetext{
${ }^{4}$ LEUPOLT, B.; BARBIERI, C. R.; JESUS L.; PÖPPL, A. G. Prevalence and Risk Factors for Urinary Incontinence in Bitches Five Years After Ovariohysterectomy. Arquivo Brasileiro de Medicina Veterinária e Zootecnia. Ahead of print.
} 
between tail docking and incontinence is not widely accepted (DE BLESER et al.; 2009).

A study has shown that bitches' overweight in the moment of neutering are 3,5 times more likely to develop incontinence than those with a balanced weight (ANGIOLETTI et al., 2004). Even though another study has not identified overweight as risk factor for incontinence in bitches (BYRON et al., 2017), it is likely that obesity is indeed a risk factor, once intra-abdominal fat deposition represents structural alteration and may alter intra-abdominal and/or urethral pressures, enabling and/or aggravating USMI (APPLEGATE, OLIN and SABATINO, 2018; PEGRAM et al., 2019).

Regarding animal's age, there are divergences. Some studies suggested that spaying bitches before 3 months old predispose them to the disease (THRUSFIELD, HOLT and MUIRHEAD, 1998). However, studies that include bitches spayed after 4 months of age or older do not show a relationship between age at neutering and occurrence of incontinence. After several reviews, authors have concluded there really seems to be a weak relationship between such factors and there is, thus, evidence that the earlier the neutering procedure is done, more likely the bitch is to develop future incontinence (BEAUVAIS, BRODBELT and CARDWELL, 2012). It has been proposed that LH or FSH plasmatic levels along with animal's age could predict the chance to develop urinary incontinence in about $80 \%$ of bitches (REICHLER et al., 2005). Nonetheless, a recent and large casecontrol study conducted in the United Kingdom has also shown absence of relationship between age at neutering and risk of USMI (PEGRAM et al., 2019). The same authors, however, point out that the risk for USMI after neutering is associated with aging and weight gain.

Despite that, even when faced with populational evidence that point towards neutering being, itself, the main risk factor for USMI, and not age at neutering, it is recommended that the expected adult weight for a large 
breed bitch be taken into consideration when choosing age to neuter the animal (BYRON et al., 2017). Thus, for bitches whose expected weight is over 25kg, especially in predisposed breeds, later spaying should be considered, when the dog will have already been through puberty (BYRON et al., 2017), whereas in small sized bitches, opting for spaying before the

first estrus is unlikely to cause the disease (SALAS et al., 2015). A study conducted with the German Shepherd breed showed that 7\% of bitches spayed before one year of age developed USMI, against no incontinent intact females and a lower incidence of incontinence when neutered after 1 year of age, which suggests that for this breed, postponing spaying reduced the risk of incontinence (HART et al., 2016).

Some factors such as intrapelvic bladder, short urethra and hypoplastic vulva have also been associated to incontinence by USMI (VOORWALD, TIOSO and TONIOLLO, 2010; APPLEGATE, OLIN and SABATINO, 2018).

\section{Clinical signs and diagnosis}

In general, urinary incontinence is more frequent in middle aged, middle sized or large dogs, and must be differentiated from inappropriate urination, pollakiuria and polyuria (ROSS, 2013; APPLEGATE, OLIN and SABATINO, 2018). Clinical signs of incontinence are normal micturition with dribbling, frequently happening as the animal lies down or relaxes/sleeps, occurring in a standing position in more serious cases. Diagnosis of USMI is based on anamnesis, physical examination, absence of alterations in urinalysis, exclusion of causes of pollakiuria (urolithiasis, cystitis, bladder neoplasms) and of polyuria/polydipsia, combined with a satisfactory response to therapy (WARE, 2006). As an acquired condition, determining the beginning of clinical signs and evolution of the affection are important (BYRON, 2015). The golden standard in the diagnosis includes 
the performance of urethral pressure profile and cystometry (ROSS, 2013). Nonetheless, bitches presenting with post-neutering incontinence and not showing signs of urinary tract-related comorbidities can be presumptively diagnosed with USMI (BYRON, 2015).

\section{Treatment of post-neutering incontinence}

Estrogens and a-adrenergic agonists are the most used drugs in the treatment of incontinence (ROSS, 2013; APPLEGATE, OLIN and SABATINO, 2018). The use of a-adrenergic agonists as monotherapy proves to be effective, but in more serious cases, estrogen hormonal reposition may be associated with the treatment (WARE, 2006; APPLEGATE, OLIN and SABATINO, 2018).

Estrogens are used to treat both incontinence in post-menopausal women and post-neutering incontinence in bitches, once they have trophic effect on vasculature and mucosa of urogenital tract, as well as on circulating collagen. This happens because these structures are estrogen dependent. When the a-adrenergic receptors expression in the urethra's smooth muscle is increased by estrogen, the hormone also increases organ sensitivity to a-adrenergic agonists, which largely contributes to the urethral closing pressure. Similarly, a-adrenergic agonists act on urethral smooth muscle receptors increasing their tonus (ROSS, 2013).

Estrogen diethylstilbestrol (DES) posology is from 0.1 to $0.3 \mathrm{mg} / \mathrm{kg}$, orally every 24 hours from three to five days, followed by a weekly dose of 1 mg per dog maximum. Even though treatment with DES is widely spread, it is no longer recommended for USMI therapy due to the potential complications of carcinogenesis and myelosuppression (APPLEGATE, OLIN and SABATINO, 2018). Alternative option would be the use of ethynyl estradiol $0.03 \mathrm{mg} / \mathrm{kg}$, orally following the same protocol as DES, or $1 \mathrm{mg}$ of estriol, orally every 24 hours, regardless of the dog's weight for one or two 
weeks. In case of relapses, treatment with DES or ethynyl estradiol can be repeated with caution, taking into consideration possible side effects, such as aplastic anemia, thrombocytopenia, and leukopenia (ZAYED, ESCH and McCONNEL, 1998).

When treatment with ethynyl estradiol is not effective, dose can be increased from 2 to $3 \mathrm{mg} / \mathrm{day}$. On the other hand, when response happens after the initial period of use, a reduction in dose to $0.5 \mathrm{mg} /$ day or even 0.25 $\mathrm{mg} /$ day or $0.5 \mathrm{mg} /$ day in alternate days can be tested (APPLEGATE, OLIN and SABATINO, 2018). Hence, when the use of estrogen is the chosen therapy, it is important that treatment be monitored through exams that evaluate hematologic parameters and hepatic function (PLUMB, 2011).

Estriol, which is an approved drug in the USA and Europe, is the most recommended option when estrogen is the chosen therapy for dogs with USMI (APPLEGATE, OLIN and SABATINO, 2018). Even though it is considered a safe drug, estriol can cause side effects such as estrus manifestation, vulvar edema, and occasional serosanguinous vaginal discharge. Therapy's goal is to find the lowest dose capable of maintaining patient's continence (ACIERNO and LABATO, 2019). According to author's experience (A.G.P), estriol-based vaginal creams available for humans can also be used 2-3 times a week as an alternative to oral medication. Even though treatment with estrogens presents several advantages, it is important to note that according to some author's opinions, complications associated with the use of estrogens overcome the benefits (APPLEGATE, OLIN and SABATINO, 2018).

There are reports on GnRH use in the post-neutering incontinence treatment. A study was conducted where $\mathrm{GnRH}$ analogues were used in incontinent bitches. This research has obtained success treating incontinence with these drugs both as monotherapy and associated to aadrenergic drugs, reducing levels of circulating LH and FSH and without the occurrence of any side effects (REICHLER et al., 2003). A later study 
by the same researchers evaluated FSH and LH levels in spayed continent and incontinent bitches and documented that although the serum concentration of these gonadotropic hormones is higher in spayed female dogs when compared to intact ones, spayed continent bitches presented higher levels than those spayed and incontinent (REICHLER et al., 2005). Such results have raised the hypothesis that low LH and FSH levels in spayed incontinent bitches are a consequence of a low production of GnRH endogenous, which justifies not only therapy success with $\mathrm{GnRH}$ analogues but also points to low production of $\mathrm{GnRH}$ as one of the post-neutering incontinence mechanisms. A third subsequent study by the same authors noted that although GnRH lowers levels of circulating gonadotropins in spayed bitches, it does not affect urethral closure, even though treatment had significant effect in the bladder's capacity to retain urine (REICHLER et al., 2006). Although usage of GnRH analogues presents a prohibitive cost, it was only effective in $75 \%$ of cases, in relation to the $90 \%$ of success when treating USMI with phenylpropanolamine (REICHLER et al., 2003; REICHLER et al., 2006). The combined use of sympathomimetic drugs and $\mathrm{GnRH}$ agonists can, however, control 100\% of cases (REICHLER et al., 2003).

Among sympathomimetic drugs, the most widely used one in the world to treat USMI is phenylpropanolamine, selective a-adrenergic receptors drug, with potential to cause less side effects (BYRON, 2015). Nevertheless, its usage is prohibited in Brazil due to its side effects in humans, such as risk of acute myocardial infarction (BRASIL, 2000). Phenylpropanolamine is also subjected to the control of authorities in many other countries due to its potential use in the production of illicit substances (ACIERNO and LABATO, 2019). Pseudoephedrine would be another option, although it does not show superiority to phenylpropanolamine regarding urodynamic variables and it is more associated with side effects with risk of toxicity (BYRON et al., 2007). Therefore, sympathomimetic drugs, even 
though effective, present frequent side effects in dogs, such as increased ocular pressure, hyperglycemia, anxiety, irritability, vomiting, anorexia, tachycardia, and hypertension (ACIERNO and LABATO, 2019), making this drug class illegible to many patients, such as diabetic, hypertensive or glaucoma patients, for instance. Posology for the aforementioned drugs can be found in Table 1.

Another drug option, little explored in veterinary medicine, is the use of tricyclic antidepressants such as imipramine and amitriptyline. These drugs are used in humans in the treatment of nocturnal enuresis once they present urinary retention as side effect. Their action mechanism involves anticholinergic and a-adrenergic actions, with fewer side effects when compared to adrenergic agonists. Such drugs are usually used in small animal practice in the treatment of behavioral disturbances, idiopathic cystitis, and cataplexy, and as adjuvants in the treatment of pruritus and occasionally of chronic pain (PLUMB, 2011).

Table 1. Main medical therapies used in the treatment of USMI according to the consulted literature.

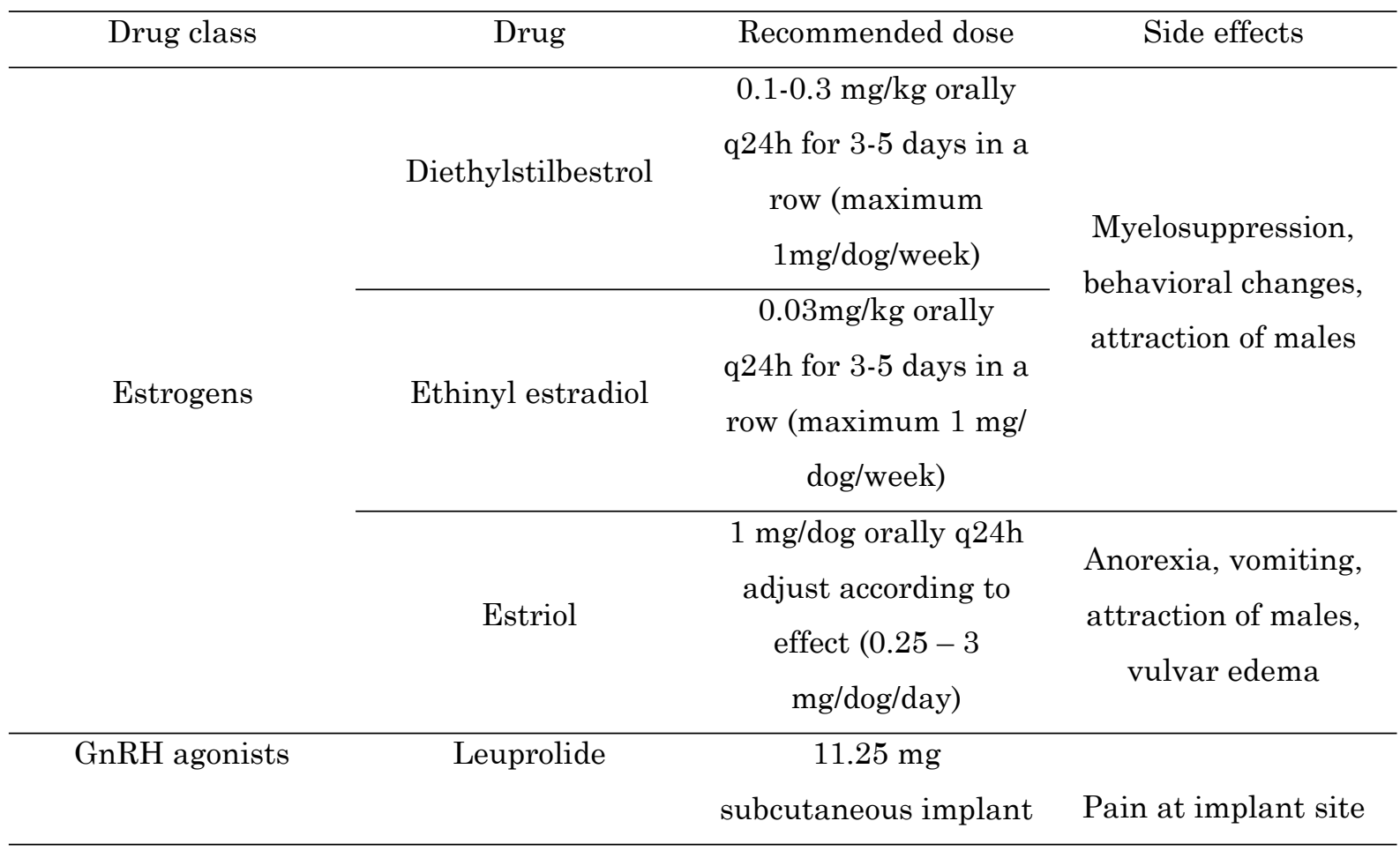




\begin{tabular}{|c|c|c|c|}
\hline & Deslorelin & $\begin{array}{c}5 \mathrm{mg} \text { subcutaneous } \\
\text { implant }\end{array}$ & and estrus signs \\
\hline \multirow{2}{*}{ Sympathomimetics } & Phenylpropanolamine & $2 \mathrm{mg} / \mathrm{kg}$ orally $\mathrm{q} 12 \mathrm{~h}$ & \multirow{2}{*}{$\begin{array}{c}\text { Anxiety, irritation, } \\
\text { vomiting, anorexia } \\
\text { tachycardia, } \\
\text { hypertension }\end{array}$} \\
\hline & Pseudoephedrine & $\begin{array}{c}1.5 \mathrm{mg} / \mathrm{kg} \text { orally q8- } \\
12 \mathrm{~h}\end{array}$ & \\
\hline \multirow{2}{*}{$\begin{array}{c}\text { Tricyclic } \\
\text { antidepressants }\end{array}$} & Imipramine & $\begin{array}{c}5-15 \mathrm{mg} / \mathrm{kg} \text { via oral } \\
\mathrm{q} 12 \mathrm{~h}\end{array}$ & \multirow{2}{*}{$\begin{array}{l}\text { Sedation, } \\
\text { gastrointestinal } \\
\text { signs, tremors, } \\
\text { constipation }\end{array}$} \\
\hline & Amitriptyline & $\begin{array}{l}1-2 \mathrm{mg} / \mathrm{kg} \text { orally q } 24 \mathrm{~h} \\
\text { adjust according to } \\
\text { effect }\end{array}$ & \\
\hline
\end{tabular}

According to our experience in treating post-neutering USMI with amitriptyline, we have started with $1 \mathrm{mg} / \mathrm{kg}$ every 12 hours and obtained success in over $60 \%$ of cases. After two weeks, non-responsive cases can have their dose adjusted to $2 \mathrm{mg} / \mathrm{kg}$ every 12 hours or $1 \mathrm{mg} / \mathrm{kg}$ every 8 hours. However, if no efficacy is seen, different treatment is recommended. We observed some patients responding to the initial dose of $1 \mathrm{mg} / \mathrm{kg}$ every 12 hours, can maintain continence with $1 \mathrm{mg} / \mathrm{kg}$ every 24 hours and, in cases where therapy was discontinued, kept continent for days or weeks without medication, with incontinence relapsing after a certain period.

No side effects of sedation, agitation, hypertension, constipation, nor hematologic alterations, hepatic, or kidney function alterations either were observed with use of tricyclic antidepressants in the long term ${ }^{5}$. Partial results of a randomized clinical trial comparing the efficacy of amitriptyline (1 mg/every 12 hours) and estriol ( $1 \mathrm{mg} / \mathrm{dog}$ every $24 \mathrm{~h}$ ) for treatment of bitches with USMI has been demonstrating the same efficacy with both treatments despite some differences regarding patient behavior between the groups. Dog owners in the amitriptyline group have reported calmer behavior after starting the treatment, whereas dog owners in the estriol

\footnotetext{
${ }^{5}$ Unpublished data.
} 
group have reported increase in activity level and occasional attraction of males (OLIVEIRA and PÖPPL, 20206).

Drug therapy is the first choice in USMI incontinence cases, but when a patient does not respond or tolerate treatment, surgical intervention could be performed. Some of the surgical techniques used are: colposuspension, vaginal suspension with transobturator tape and urethropexy; all with variable outcomes and questionable efficacy in the long term (GRAND, BUREAU and MONNET, 2013; MARTINOLI, NELISSEN and WHITE, 2014; REICHLER and HUBLER, 2014; BYRON, 2015; DESCHAMPS and ROUX, 2015). A seemingly promising surgical alternative is the application of hydraulic artificial urethral sphincter (HAUS); when tested it was considered effective for the treatment of USMI associated to a low level of complications (MORGAN et al., 2018). Colposuspension was considered for many years as standard treatment for USMI until the creation of artificial urethral sphincters. Prospective studies have been trying to compare both techniques to determine which one has a greater efficacy (OWEN, 2016).

Another alternative therapy is collagen injections use or injections of some other volume-inducing agent in the urethral submucosa, which increase the extension of muscle fibers and, consequently, their closing capacity, improving continence (APPLEGATE, OLIN and SABATINO, 2018). Cellular therapy, with application of skeletal muscle precursor cells injected in the urethral sphincter site, may be effective option in the future (WILLIAMS et al., 2015).

\section{Conclusions}

Untreated urinary incontinence, besides having negative impact on the female dog life affected, also jeopardizes the relationship between the

${ }^{6}$ OLIVEIRA, M. C.; PÖPPL, A. G. Efeito da amitriptilina em relação ao estriol sistêmico no controle da incontinência urinária pós-castração em cadelas. In: Salão de Iniciação Científica da UFRGS, 32., 2020, Porto Alegre. Anais XXXII SIC. Porto Alegre: UFRGS, 2020. 
dog and its owner, which is a closer one nowadays, and could lead to frustrations that culminate in abandonment or even euthanasia. Nevertheless, keeping in mind all the differential diagnosis for urinary incontinence is important, as being aware of therapeutic options, their possible side effects and the costs involved with maintenance and monitoring of treatment. More research is necessary both for the disease's pathophysiology understanding as well as the possibility for further investigation of more efficacious treatments. Besides, clarifying dog owners about the risk factors for urinary incontinence when they opt for elective neutering surgery is believed to be important.

\title{
Incompetência do mecanismo do esfíncter urinário pós-castração em cadelas - revisão de literatura
}

\begin{abstract}
Resumo: A castração de fêmeas caninas é uma cirurgia de rotina que visa principalmente a prevenção de doenças e o controle populacional da espécie. Ela não é, todavia, desprovida de consequências indesejáveis, e a incontinência urinária pós-castração é uma das mais significativas. Tratamento medicamentoso é preconizado para estes casos, sendo o emprego dos fármacos a-adrenérgicos e estrogênicos os mais frequentemente descritos na literatura. Entretanto, o uso de antidepressivos tricíclicos pode ser eficaz no controle dos sinais clínicos da incontinência. O mecanismo exato que envolve esta afecção ainda não é completamente entendido. Acredita-se que uma deficiência de estrógeno e consequente perda de tônus uretral sejam responsáveis pela ocorrência dos sinais, mas é possível que outros fatores como os níveis de gonadotrofinas e de hormônio liberador de gonadotrofinas estejam implicados na patogenia da incontinência urinária pós-castração.

Palavras-chave: gonadectomia, incontinência urinária, deficiência de estrógeno, gonadotrofina, antidepressivos tricíclicos, Canis lupus familiaris.
\end{abstract}




\section{References}

ABRAMS, P.; CARDOZO, L.; FALL, M.; GRIFFTHS, D.; ROSIER, P.; ULMSTEN, U.; VAN KERREBROECK, P.; VICTOR, A.; WEIN, A. The standardisation of terminology of lower urinary tract function: report from the Standardisation Subcommittee of the International Continence Society. Neurourology and Urodynamics, v. 21, n. 2, p. 167-178, 2002. https://doi.org/10.1002/nau.10052

ACIERNO, M. J.; LABATO, M. A. Canine incontinence. Veterinary Clinics of North America: Small Animal Practice, v. 49, n. 2, p. 125-140, 2019. https://doi.org/ 10.1016/j.cvsm.2018.11.003

ANGIOLETTI, A.; DE FRANCESO, I.; VERGOTTINI, M.; BATTOCCHIO, M. L. Urinary incontinence after spaying in the bitch: incidence and oestrogen-therapy. Veterinary Research Communications, v. 28, n. 1, p. 153-155, 2004. https://doi.org/10.1023/B:VERC.0000045394.31433.9e

APPLEGATE, R.; OLIN, S.; SABATINO, B. Urethral sphincter mechanism incompetence in dogs: an update. Journal of the American Animal Hospital Association, v. 54, n. 1, p. 22-29, 2018. https://doi.org/10.5326/JAAHA-MS-6524

ARNOLD, S.; ARNOLD, P.; HUBLER, M.; CASAL, M.; RÜSCH, P. Urinary incontinence in spayed female dogs: frequency and breed disposition. Schweiz Arch Tierheilkd, v. 131, n. 5, p. 259-263, 1989.

AUGSBURGER, H. R.; OSWALD, M. Immunohistochemical analysis of collagen types I, III, IV and a-actin in the urethra of sexually intact and ovariectomized beagles. International Urogynecology Journal, v. 18, n. 9, p. 1071-1075, 2007. https://doi.org/10.1007/s00192-006-0272-x

BARTGES, J. W.; CALLENS, A. J. Congenital diseases of the lower urinary tract. Veterinary Clinics of North America: Small Animal Practice, v. 45, n. 4, p. 703-719, 2015. https://doi.org/10.1016/j.cvsm.2015.02.004 
BATRA, S. C.; IOSIF, C. S. Female urethra: a target for estrogen action. British Journal of Urology, v. 129, n. 2, p. 418-420, 1983. https://doi.org/10.1016/S0022$\underline{5347(17) 52129-1}$

BEAUVAIS, W.; BRODBELT, D. C.; CARDWELL, J. M. The effect of neutering on the risk of urinary incontinence in bitches - a systematic review. Journal of Small Animal Practice, v. 53, n. 4, p. 198-204, Abril 2012. https://doi.org/10.1111/j.1748$\underline{5827.2011 .01176 . x}$

BEHREND, E.N. Canine Hyperadrenocorticism. In: FELDMAN, C. E.; NELSON, R. W.; REUSCH, C.; SCOTT-MONCRIEFF, J. C, BEHREND, E. Canine \& Feline Endocrinology. 4. ed. St. Louis, Editora Elsevier, 2015, cap.10, p. 377-451. https://doi.org/10.1016/B978-1-4557-4456-5.00010-9

BRASIL. Resolução $\mathrm{n}^{0} .96$ de 8 de novembro de 2000. Proíbe o uso da Fenilpropanolamina. Diário Oficial [da] União, Poder Executivo, Brasília, DF, 8 nov. 2000. Disponível em: <http://bvsms.saude.gov.br/bvs/saudelegis/anvisa/2000/ res0096 0811 2000.html.> Acesso em: 11 nov. 2019.

BYRON, J. K.; TAYLOR, K. H.; PHILLIPS, G. S.; STAHL, M. S. Urethral Sphincter Mechanism Incompetence in 163 Neutered Female Dogs: Diagnosis, Treatment, and Relationship of Weight and Age at Neuter to Development of Disease. Journal of Veterinary Internal Medicine, v. 31, n. 2, p. 442-448, 2017. https://doi.org/10.1111/jvim.14678

BYRON, J. K. Micturition Disorders. Veterinary Clinics of North America: Small Animals Practice, v. 45, n. 4, p. 1-14, 2015. https://doi.org/10.1016/j.cvsm.2015.02.006

BYRON, J. K.; GRAVES, T. K.; BECKER, M. D.; COSMAN, J. F.; LONG, E. M. Evaluation of the ratio of collagen type III to collagen type I in periurethral tissues of sexually intact and neutered female dogs. American Journal of Veterinary Research, v. 71, n. 6, p. 697-700, 2010. https://doi.org/10.2460/ajvr.71.6.697 
BYRON, J. K.; MARCH, P. A.; CHEW, D. J.; DIBARTOLA, S.P. Effect of Phenylpropanolamine and Pseudoephedrine on the Urethral Pressure Profile and Continence Scores of Incontinent Female Dogs. Journal of Veterinary Internal Medicine, v. 21, n. 1, p. 47-53, 2007. https://doi.org/10.1111/j.19391676.2007.tb02927.x

CALlARD, J.; McLOUGHLIN, M. A.; BYRON, J. K.; CHEW, D. J. Urinary Incontinence in Juvenile Female Soft-Coated Wheaten Terriers: Hospital Prevalence and Anatomic Urogenital Anomalies. Journal of the American Hospital Association, v. 52, n. 1, p. 27-35, 2016. https://doi.org/10.5326/JAAHA-MS-6220

CESARE, T. D.; FERRARI, S.; ROMAGNOLI, S. Ocorrência de incontinência urinária em cadelas castradas no Hospital Veterinário da Universidade AnhembiMorumbi, São Paulo, Brasil. Brazilian Journal of Veterinary Research and Animal Science, v. 50, n. 3, p. 184-187, 2013.

CHARLtON, R. G.; MORLEY, A. R.; CHAMBERS, P.; GILlESPIE, J. I. Focal changes in nerve, muscle, and connective tissue in normal and unstable human bladder. British Journal of Urology International, v. 84, n. 9, p. 953-960, 1999. https://doi.org/10.1046/j.1464-410x.1999.00360.x

CHEN, B. H.; WEN, Y.; LI, H.; POLAN, M.L. Collagen metabolism and turnover in women with stress urinary incontinence and pelvic prolapse. International Urogynecology Journal, v. $\quad$ 13, n. 2, p. 80-87, 2002. https://doi.org/10.1007/s001920200020

COIT, V. A.; GIBSON, I. F.; EVANS, N. P.; DOWELL, F. J. Neutering affects urinary bladder function by different mechanisms in male and female dogs. European Journal of Pharmacology, v. 584, n. 1, p. 153-158, 2008. https://doi.org/10.1016/j.ejphar.2008.02.037 
COIT, V. A.; DOWELL, F. J.; EVANS, N. P. Neutering Affects mRNA expression levels for the LH- and GnRH- receptors in the canine urinary bladder. $\begin{array}{lllllll}\text { Theriogenology, } & \text { v. } & 71, & \text { n. } & 2, & \text { p. } & 239-247,\end{array}$ https://doi.org/10.1016/j.theriogenology.2008.06.093

CORRIVEAU, K. M.; GIUFFRIDA, M. A.; MAYHEW, P. D.; RUNG, J. J. Outcome of laparoscopic ovariectomy and laparoscopic-assisted ovariohysterectomy in dogs: 278 cases (2003-2013). Journal of the American Veterinary Medical Association, v. 251, n. 4, p. 443-450, 2017. https://doi.org/10.2460/javma.251.4.443

DE BLESER, B.; BRODBELT, D. C.; GREGORY, N. G.; MARTINEZ, T.A. The association between acquired urinary sphincter mechanism incompetence in bitches and early spaying: A case-control study. The Veterinary Journal, v. 187, n. 1, p. 42-47, 2009. https://doi.org/10.1016/j.tvjl.2009.11.004

DESCHAMPS, J. Y.; ROUX, F. A. Transobturator vaginal tape for treatment of urinary incontinence in spayed bitches. Journal of the American Hospital Association, v. 51, n. 2, p. 85-96, 2015. https://doi.org/10.5326/JAAHA-MS-6215

DYCE, K. M.; WENSING, C. J. G.; SACK, W. O. O Aparelho Urogenital. In: DYCE, K. M.; WENSING, C. J. G.; SACK, W.O. Tratado de Anatomia Veterinária. 3. ed. Rio de Janeiro: Editora Elsevier, 2004. 164-207 p.

GOFF, J. P. Cartilage, Bones and Joints. In: REECE, W.O. Duke's physiology of domestic animals. 13. ed. Iowa.Wiley Blackwell, 2015. cap. 50, p.593-616.

GRAND, J. G.; BUREAU, S.; MONNET, E. Effects of urinary bladder retroflexion and surgical technique on postoperative complication rates and long-term outcome in dogs with perineal hernia: 41 cases (2002-2009). Journal of the American Veterinary Medical Association, v. 243, n. 10, p.1442-1447, 2013. https://doi.org/10.2460/javma.243.10.1442 
GREGORY, S. P. Developments in the understanding of the pathophysiology of urethral sphincter mechanism incompetence in the bitch. British Veterinary Journal, v. 150, n. 2, p. 135-150, 1994. https://doi.org/10.1016/S00071935(05)80222-2

HART, B. L.; HART, L. A.; THIGPEN, A. P.; WILLITS, N.H. Neutering of German Shepherd Dogs: associated joint disorders, cancers, and urinary incontinence. Veterinary Medicine and Science, v. 2, n. 3, p. 191-199, 2016. https://doi.org/10.1002/vms3.34

HARVEY, R. A.; FERRIER, D. R. Metabolismo dos Lipídeos Complexos. In: Bioquímica Ilustrada. 5. ed. Porto Alegre: Artmed, 2012, cap.17, p.201-218.

HEESCH, C. M.; KLINE, D. D.; HASSER, E. M Control Mechanisms of the Circulatory System. In: REECE, W.O. Duke's physiology of domestic animals. 13. ed. Iowa: Wiley Blackwell, 2015. Cap. 35, p.352-361.

HOLT, P. E.; THRUSFIELD, M. V. Association between breed, size, neutering, and docking, and acquired urinary incontinence due to incompetence of the urethral sphincter mechanism. Veterinary Record, v. 133, n. 8, p. 177-180, 1993. https://doi.org/10.1136/vr.133.8.177

JOSHUA, J. O. The spaying of bitches. Veterinary Record, v. 77, n. 23, p. 642-646, 1965.

MARTINOLI, S.; NELISSEN, P.; WHITE, R. A. The outcome of combined urethropexy and colposuspension for management of bitches with urinary incontinence associated with urethral sphincter mechanism incompetence. Veterinary Surgery, v. 43, n. 1, p. 52-57, 2014. https://doi.org/10.1111/j.1532$\underline{950 X .2013 .12084 . x}$

MATSUBARA, S.; OKADA, H.; SHIRAKAWA, T.; GOTOH, A.; KUNO, T.; KAMIDONO, S. Estrogen levels influence beta-3-adrenoceptor-mediated relaxation 
of the female rat detrusor muscle. Urology, v. 59, n. 4, p. 621-625, 2002. https://doi.org/10.1016/S0090-4295(01)01583-7

MITRANO, P.; NOGUEIRA, M. D.; FELDNER JR, P. C.; CASTRO, R. A.; SARTORI, M. G.F.; NADER, H. B.; GIRÃO, M. J. B. C. Metabolic profile of glycosaminoglycans in bladder and urethra of female rats during and after pregnancy. International Urogynecology Journal, v. 21, n. 2, p. 241-246, 2010. https://doi.org/10.1007/s00192-009-1001-z

MOALlI, P. A.; TALARICO, L. C.; SUNG, V. W.; KLINGENSMITH, W. L.; SHAND, S. H.; MEYN, L. A.; WATKINS, S. C. Impact of menopause on collagen subtypes in arcus tendineous fasciae pelvis. American Journal of Obstetrics \& Gynecology, v. 190, n. 3, p. 620-627, 2004. https://doi.org/10.1016/j.ajog.2003.08.040

MORGAN, M.; FORMAN, M. Cystoscopy in dogs and cats. Veterinary Clinics of North America: Small Animal Practice, v. 45, n. 4, p. 665-701, 2015. https://doi.org/ 10.1016/j.cvsm.2015.02.010

MORGAN, K.; MILNER, H.R.; TIKEKAR, A.; SMITH, H.L.; COOMER, A. R. Long term use of hydraulic artificial urethral sphincters in nine dogs from New Zealand with urethral sphincter mechanism incompetence. New Zealand Veterinary Journal, v. 66 , n. 4, p. 205-209, 2018. https://doi.org/10.1080/00480169.2018.1464975

NATHAN, C.; SPORN, M. Cytokines in context. Journal of Cell Biology, v. 113, n. 5, p. 981-986, 1991. https://doi.org/10.1083/jcb.113.5.981

NICKEL, R. F. Studies on the function of the urethra and bladder in continent and incontinent female dogs. The Veterinary Quarterly, v. 20, n. 1, p. 102-103, 1998. https://doi.org/10.1080/01652176.1998.10807445

NÖEL, S. M.; CLAEYS, S.; HAMAIDE, A. J. Surgical management of ectopic ureters in dogs Clinical outcome and prognostic factors for long-term continence. Veterinary Surgery, v. 46, n. 5, p. 631-641, 2017. https://doi.org/10.1111/vsu.12654 
OWEN, L. Urinary incontinence in dogs. Veterinary Record, v. 179, n. 10, p. 260, 2016. https://doi.org/10.1136/vr.i4832

PALERME, J. S.; MAZEPA, A.; HUTCHINS, R. G.; ZIGLIOLI, V.; VADEN, S. L. Clinical Response and Side Effects Associated with Testosterone Cypionate for Urinary Incontinence in Male Dogs. Journal of the American Animal Hospital Association, v. 53, n. 5, p. 285-290, 2017. https://doi.org/10.5326/JAAHA-MS-6588

PEGRAM, C.; O’NEILL, D. G.; CHURCH, D. B.; HALL, J.; OWEN, L.; BRODBELT, D. C. Spaying and urinary incontinence in bitches under UK primary veterinary care: a case-control study. Journal of Small Animal Practice, v. 60, n. 7, p. 395-403, 2019. https://doi.org/10.1111/jsap.13014

PLUMB, D. C. Veterinary Drug Handbook. 7 ed. Wisconsin: Pharma VetInc, 2011. p. $67-69 ; 398-399 ; 744-746$.

PONGLOWHAPAN, S.; CHURCH, D. B.; KHALID, M. Expression of prostaglandin $\mathrm{E}_{2}$ receptor subtype in the canine lower urinary tract varies according to the gonadal status and gender. Theriogenology, v. 74, n. 8, p. 1450-1466, 2010. https:// doi.org/10.1016/j.theriogenology.2010.06.017

PONGLOWHAPAN, S.; CHURCH, D. B.; KHALID, M. Effect of the gonadal status and the gender on glycosaminoglycans profile in the lower urinary tract of dogs. Theriogenology, v. 76, n. 7, p. 1284-1292, 2011. https://doi.org/10.1016/j.theriogenology.2011.05.035

PONGLOWHAPAN, S.; CHURCH, D. B.; KHALID, M. Differences in the proportion of collagen and muscle in the canine lower urinary tract with regard to gonadal status and gender. Theriogenology, v. 70, n. 9, p. 1516-1524, 2008. https:// doi.org/10.1016/j.theriogenology.2008.06.099 
PONGLOWHAPAN, S.; CHURCH, D. B.; SCARAMUZZI, R.J.; KHALID, M. Luteinizing and follicle-stimulating hormone receptors and their transcribed genes (mRNA) are present in the lower urinary tract of intact male and female dogs. $\begin{array}{lllllll}\text { Theriogenology, } & \text { v. } \quad 67, \quad \text { n. } & 2, & \text { p. } & 353-366, & \end{array}$ https://doi.org/10.1016/j.theriogenology.2006.08.007

PÖPPL, A. G.; CARVAlHO, G. L. C.; VIVIAN, I. F.; CORBELlinI, L. G.; GONZÁLEZ, F. H. D. Canine diabetes mellitus risk factors: A matched case-control study. Research in Veterinary Science, v. 114, p. 469-473, Agosto 2017. https://doi.org/10.1016/j.rvsc.2017.08.003

REECE, W. O. The Renal System: Structures and Function. In: REECE, W.O. Duke's physiology of domestic animals. 13. ed. Iowa: Wiley Blackwell, 2015. Cap. 15, p. 157-165. (a)

REECE, W. O. Micturition, Characteristics of Urine, and Renal Clearance. In: REECE, W.O. Duke's physiology of domestic animals. 13. ed. Iowa: Wiley Blackwell, 2015. Cap. 19, p. 188-192. (b)

REECE, W.O. Female Reproduction in Mammals. In: REECE, W.O. Duke's physiology of domestic animals. 13. ed. Iowa: Wiley Blackwell, 2015. Cap. 53, p. 670-693. (c)

REICHLER, I. M.; HUBLER, M. Urinary incontinence in the bitch: an update. Reproduction in Domestic Animals, v. 49, n. 2, p. 75-80, 2014. https://doi.org/10.1111/rda.12298

REICHLER, I. M.; HUNG, E.; JÖCHLE, W.; PICHÉ, C. A.; ROOS, M.; HUBLER, M.; ARNOLD, S. FSH and LH plasma levels in bitches with differences in risk for urinary incontinence. Theriogenology, v. 63, n. 8, p. 2164-2180, 2005. https://doi.org/10.1016/j.theriogenology.2004.09.047 
REICHLER, I. M.; HUBLER, M.; JöCHLE, W.; TRIGG, T. E.; PICHÉ, C. A.; ARNOLD, S. The effect of GnRH analogs on urinary incontinence after ablation of the ovaries in dogs. Theriogenology, v. 60, n. 7, p. 1207-1216, 2003. https://doi.org/10.1016/S0093-691X(02)01368-7

REICHLER, I. M.; BARTH, A.; PICHÉ, C. A.; JÖCHLE, W.; ROOS, M.; HUBLER, M.; ARNOLD, S. Urodynamic parameters and plasma LH/FSH in spayed Beagle bitches before and 8 weeks after GnRH depot analogue treatment. Theriogenology, v. 66 , n. 9, p. 2127-2136, 2006. https://doi.org/10.1016/j.theriogenology.2006.06.009

REKERS, H.; DROGENDIJK, A. C.; VALKENBURG, H. A.; RIPHAGEN, F. The menopause, urinary incontinence, and other symptoms of the genito-urinary tract. Maturitas, v. 15, n. 2, p. 101-111, 1992. https://doi.org/10.1016/0378-5122(92)90244$\underline{\mathrm{X}}$

RICHTER, K. P.; LING, G. V. Clinical response, and urethral pressure profile changes after phenylpropanolamine in dogs with primary sphincter incompetence. Journal of the American Veterinary Medical Association, v. 187, n. 6, p. 605-611, 1985.

ROBINSON, D.; CARDOZO, L. D. The role of estrogens in female lower urinary tract dysfunction. Urology. v. 62, n. 4 suppl 1, p. 45-51, Outubro, 2003. https://doi.org/10.1016/S0090-4295(03)00676-9

ROSS, S. Urinary Incontinence: when good dog leaks. Apostila do curso de aperfeiçoamento à distância. MedVetTeam, 2013.

SALAS, Y.; MÁRQUEZ, A.; DIAZ, D.; ROMERO, L. Epidemiological Study of Mammary Tumors in Female Dogs Diagnosed during the Period 2002-2012: A Growing Animal Health Problem. Plos One, v. 10, n. 5, p. 1-15, Maio 2015. https://doi.org/10.1371/journal.pone.0127381 
SCHREITER, F.; FUCHS, P.; STOCKAMP, K. Estrogenic Sensitivity of aReceptors in the Urethra Musculature. Urologia Internationalis, v. 31, n. 1-2, p. 1319, 1976. https://doi.org/10.1159/000280026

TANAGHO, E.A. Anatomy of the genitourinary tract. In: TANAGHO, E. A, MCANINCH, J.W, eds. Smith's General Urology. 17. ed. Nova York: McGraw-Hill, 2008. Cap. 1, p. 1-16. DOI: $10.1036 / 0071457372$

THRUSFIELD, M. V.; HOLT, P. E.; MUIRHEAD, R. H. Acquired urinary incontinence in bitches: Its incidence and relationship to neutering practices. Journal of Small Animal Practice, v.39, n. 12, p.559-566, 1998. https://doi.org/10.1111/j.1748-5827.1998.tb03709.x

USHIKUBI, F.; HIRATA, M.; NARUMIYA, S. Molecular biology of prostanoid receptors; an overview. Journal of Lipid Mediators Cell Signalling, v. 12, n. 2-3, p. 343-359, 1995. https://doi.org/10.1016/0929-7855(95)00022-I

VOORWALDI, F. A.; TIOSSO, C. F.; TONIOLLO, G. H. Incontinência urinária após gonadectomia em fêmeas caninas. Ciência Rural, v. 40, n. 3, p. 718-726, 2010.

WARE, W. A. Distúrbios do Trato Urinário. In: NELSON, R.W.; COUTO, C.G. Medicina interna de pequenos animais. 3.ed. Rio de Janeiro: Guanabara Koogan, 2006. Cap. 41, p. 547-562.

WELLE, M. M.; REICHLER, I. M.; BARTH, A.; FORSTER, U.; SATTLER, U.; ARNOLD, S. Immunohistochemical localization and quantitative assessment of GnRH-, FSH-, and LH-receptor mRNA Expression in canine skin: a powerful tool to study the pathogenesis of side effects after spaying. Histochemestry and Cell Biology, v. 126, n. 5, p. 527-535, 2006. https://doi.org/10.1007/s00418-006-0189-y 
WILLIAMS, J. K.; ECKMAN, D.; DEAN, A.; MORADI, M.; ALLICKSON, J.; CLINE, J.M.; YOO, J. J.; ATALA, A. The dose-effect safety of skeletal muscle precursor cell therapy in a dog model of intrinsic urinary sphincter deficiency. Stem Cells Translational Medicine, v. 4, n. 3, p.286-294, 2015. https://doi.org/10.5966/sctm.2014-0114

ZAYED, I.; ESCH, E.V.; McCONNEL, R.F. Systemic and Histopathologic Changes in Beagle Dogs After Chronic Daily Oral Administration of Synthetic (Ethinyl Estradiol) or Natural (Estradiol) Estrogens, with Special Reference to the Kidney and Thyroid. Toxicologic Pathology, v. 26, n. 6, p. 730-741, 1998. https://doi.org/10.1177/019262339802600603 